\title{
SWASEMBADA DAGING SAPI ANALISIS SIMULASI RAMALAN SWASEMBADA DAGING SAPI DI INDONESIA
}

\author{
Sri Handayani', Anna Fariyanti ${ }^{2}$, dan Rita Nurmalina ${ }^{2}$ \\ ${ }^{1}$ Program Studi Ilmu Ekonomi Pertanian, Sekolah Pascasarjana, Institut Pertanian Bogor \\ ${ }^{2}$ Departemen AgribisnisFakultas Ekonomi dan Manajemen, Institut Pertanian Bogor \\ E-mail: sri.meulaboh@gmail.com
}

\begin{abstract}
ABSTRAK. Tujuandaripenelitianiniadalahmenganalisis permintaan dan penawaran daging sapi di Indonesia serta melakukan simulasi peramalan terhadap permintaan dan produksi daging sapi di Indonesia yang terkait dengan program swasembada daging. Data yang digunakan merupakan data sekunder deret waktu dari 1996-2013. Analisis data dilakukan dengan beberapa tahap: 1) dengan pendekatan ekonometrika menggunakan metode 2SLS, 2) dengan analisis elastisitas dan 3) dengan analisis simulasi peramalan. Hasilpenelitian menunjukan bahwa permintaan daging sapi responsif terhadap populasi penduduk. Sedangkan pada sisi penawaran yang diwakili oleh produksi menunjukan bahwa harga daging sapi domestik, harga daging impor dan kebijakan swasembada berpengaruh nyata terhadap produksi daging sapi. Hasil peramalan menunjukkan bahwa ketergantungan Indonesia terhadap daging sapi impor akan meningkat, kebutuhan konsumsi dalam negeri akan terus dipasok oleh daging impor.
\end{abstract}

Kata kunci: swasembada daging, daging sapi, persamaan simultan.

\section{SIMULATION OF ANALYSIS FORECASTFOR BEEF SELF SUFFICIENT IN INDONESIA}

ABSTRACT. The purpose of this study are to analyze the demand and supply of beef in Indonesia and projecting the production and beef demand in Indonesia related to meat self sufficuency program. Data used is the time series data from 1996 to 2013. Data analysis was done by several stage: 1) by econometric approach using the 2SLS method, 2) by elasticity analysis and 3) by forecasting simulation analysis. The result shows that the demand for beef responsive to the population. Meanwhile, on beef suppy side which represented by production shows that significantly effect by domestic and imported price beside of the self sufficiency policies. Forecasting result indicate that the reliance Indonesia to beef imports will increase, domestic consumption will countinue to be supplied by meat imported.

Keywords: selfsufficiency, beef, simultaneous equations.

\section{PENDAHULUAN}

Komoditas peternakan mempunyai prospek yang baik untuk dikembangkan. Hal ini didukung oleh karakteristik produk yang dapat diterima oleh masyarakat Indonesia. Kondisi ini menunjukkan bahwa Indonesia merupakan pasar potensial bagi agribisnis peternakan. Hal tersebut dikarenakan jumlah penduduknya yang mencapai 220 juta jiwa dan masih akan tumbuh sebesar 1.4 persen per tahunnya. Oleh sebab itu Indonesia merupakan negara dengan jumlah konsumen yang sangat besar, dengan kondisi geografis dan sumber daya alamnya sehingga mendukung usaha dan industri peternakan. Meningkatnya kesadaran dan pengetahuan masyarakat tentang gizi serta meningkatnya pendapatan per kapita akan meningkatkan daya beli masyarakat (Daryanto 2009).

Produk daging sapi mempunyai peranan yang sangat besar terhadap perekonomian nasional, namun banyak permasalahan terjadi yang dapat menghambat pertumbuhan baik secara makro maupun mikro. Pertumbuhan produksi daging sapi yang sebesar 3.0 persen tidak sebanding dengan laju pertumbuhan impor daging yaitu sebesar 4.7 persen (Tabel 3). Hal tersebut menunjukkan bahwa pertumbuhan impor daging sapi lebih meningkat tajam dibandingkan produksi daging sapi domestiknya. Produksi daging sapi domestik belum mampu memenuhi kebutuhan konsumsi masyarakatnya. Jumlah produksi daging sapi domestik akan mempengaruhi jumlah penawaran daging sapi domestiknya. Adapun jumlah penyediaan daging di Indonesia dapat dilihat pada tabel 1 berikut.

Tabel 1. Penyediaan dan konsumsi daging sapi di Indonesia, 2009-2013 (000 ton)

\begin{tabular}{lcccccc}
\hline \multirow{2}{*}{ Uraian } & \multicolumn{5}{c}{ Tahun } & $\begin{array}{c}\text { Pertumbuhan } \\
(\%)\end{array}$ \\
\cline { 2 - 6 } & 2009 & 2010 & 2011 & 2012 & 2013 & 3,0 \\
\hline $\begin{array}{l}\text { Produksi } \\
\text { daging }\end{array}$ & 250,8 & 258,8 & 266,8 & 275,0 & 283,5 & \\
$\begin{array}{l}\text { Impor } \\
\text { daging }\end{array}$ & 70,0 & 73,4 & 77,0 & 80,8 & 84,8 & 4,7 \\
Total & 320,8 & 332,2 & 343,8 & 355,8 & 368,3 & 3,4 \\
$\begin{array}{l}\text { Konsumsi } \\
\text { daging }\end{array}$ & 325,9 & 330,0 & 334,2 & 338,4 & 342,7 & 1,2 \\
\hline
\end{tabular}

Sumber: Kementerian Pertanian (2014,diolah).

Berdasarkan kondisi dimana produksi daging sapi menunjukkan kecenderungan yang meningkat ditiap tahunnya. Namun hal tersebut belum dapat memenuhi kebutuhan konsumsi daging sapi sehingga untuk memenuhi kebutuhan tersebut dilakukannya impor.

Dalam kaitannya dengan program swasembada daging sapi yang dicetuskan sejak tahun 2000 sampai sekarang mengalami pengunduran target (moving target) sebanyak 3 kali. PSDS 2014 sebenarnya merupakan 
program lanjutan yang telah dicanangkan sebelumya sejak tahun 2001-2005. Pada waktu itu, program bernama program kecukupan daging sapi yang diartikan tersedianya secara cukup pangan hewani asal ternak khususnya daging sapi sampai tingkat rumah tangga. Pengertian ketersediaan tersebut adalah paling tidak 90 persen tersedia dari supply dalam negeri, sehingga kecukupan bersifat swasembada on trend, yang artinya pada kurun waktu tertentu dapat saja dilakukan impor (Daryanto 2011).

Oleh karena itu, penelitian ini bertujuan untuk melakukansimulasi ramalan yang menyangkut dengan program swasembada daging sapi melalui sisi permintaan dan produksi daging sapi di Indonesia.

\section{METODE PENELITIAN}

Spesifikasi model merupakan suatu upaya untuk mempelajari hubungan antar peubah dan kemudian mengekspresikan hubungan tersebut dalam bentuk persamaan matematika. Spesifikasi model ekonometrika dibuat berdasarkan pada teori ekonomi dan berbagai pengalaman empiris yang berhubungan dengan fenomena yang sedang dipelajari. Adapun persamaan tersebut adalah sebagai berikut :

1. Permintaan daging sapi domestik

Tingkat permintaan terhadap suatu barang dipengaruhi oleh harga barang itu sendiri, harga barang substitusinya, pendapatan masyarakat dan jumlah penduduk. Persamaan permintaan daging sapi domestik dirumuskan sebagai berikut :

$\operatorname{DDS}_{\mathrm{t}}=\mathrm{a}_{0}+\mathrm{a}_{1} \mathrm{HDDR}_{\mathrm{t}}+\mathrm{a}_{2} \mathrm{HDAR}_{\mathrm{t}}+\mathrm{a}_{3} \mathrm{PPNR}_{\mathrm{t}}+\mathrm{a}_{4} \mathrm{POP}_{\mathrm{t}}$ $+\mathrm{a}_{5} \operatorname{DDS}_{\mathrm{t}-1}+\mathrm{E}_{1 \mathrm{t}}$

dimana:

$\mathrm{DDS}_{\mathrm{t}}=$ permintaan daging sapi domestik (000 ton),

$\mathrm{HDDR}_{\mathrm{t}}=$ harga rill daging sapi domestik $(\mathrm{Rp} / \mathrm{Kg})$

HDAR $_{t}=$ harga rill daging ayam $(\mathrm{Rp} / \mathrm{Kg})$

$\mathrm{PPNR}_{\mathrm{t}}=$ pendapatan nasional $(\mathrm{Rp})$

$\mathrm{POP}_{\mathrm{t}}=$ populasi penduduk (000 Jiwa)

$\mathrm{DDS}_{\mathrm{t}-1}=$ lag konsumsi daging sapi domestik

$\mathrm{E}_{3 \mathrm{t}}=$ peubah pengganggu

Tanda parameter dugaan yang diharapkan : $\mathrm{a}_{2}, \mathrm{a}_{3}, \mathrm{a}_{4}>0$; $\mathrm{a}_{1}<0 ; 0<\mathrm{a}_{5}<1$

2. Penawaran Daging Sapi Domestik

Penawaran daging sapi merupakan jumlah total produksi daging sapi secara keseluruhan ditingkat nasional. Jumlah produksi yang tidak sebanding dengan konsumsi mengakibatkan adanya produk daging sapi yang diimpor. Dengan demikian penawaran daging sapi domestik dapat didefinisikan sebagai penjumlahan atara jumlah produksi daging sapi domestik dan jumlah daging sapi impor. Penawaran daging sapi domestik merupakan persamaan identitas adapun persamaannya dapat dirumuskan sebagai berikut:

$$
\begin{aligned}
& \mathrm{SDD}_{\mathrm{t}}=\mathrm{PDSD}_{\mathrm{t}}+\mathrm{MDS}_{\mathrm{t}} \\
& \text { dimana : }
\end{aligned}
$$

$\mathrm{SDD}_{\mathrm{t}}=$ penawaran Daging Sapi Domestik (000 ton)

$\mathrm{PDSD}_{\mathrm{t}}=$ produksi Daging Sapi Domestik (000 ton)

$\mathrm{MDS}_{\mathrm{t}}=$ impor Daging Sapi (000 ton)

3. Produksi Daging Sapi Domestik

Produksi daging sapi domestik bersumber dari pemotongan sapi lokal dan tambahan dari sapi bakalan impor. Pemotongan sapi dilakukan pada ternak yang telah berumur lebih dari dua tahun. Produksi ternak sapi domestik akan meningkatkan penawaran ternak sapi untuk dipotong yang berarti akan meningkatkan produksi daging sapi domestik dan permintaan daging sapinya. Populasi ternak sangat menentukan jumlah ternak sapi yang akan dipotong guna menghasilkan produk daging. Peningkatan harga daging dapat merangsang jumlah ternak yang dipotong, sehingga harga ternak tersebut sangat berpotensi meningkatkan produksi daging sapi. Jumlah sapi bakalan impor juga berpengaruh terhadap produksi daging sapi. Berdasarkan hal tersebut maka produksi daging sapi domestik dipengaruhi oleh populasi sapi nasional, harga daging sapi domestik, impor daging sapi. Adapun persamaannya dapat diformulasikan sebagai berikut:

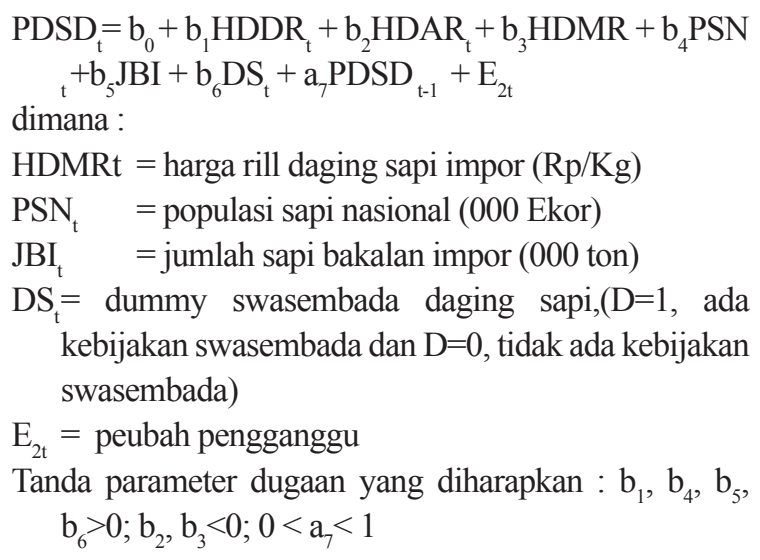

\section{Impor Daging Sapi}

Indonesia merupakan negara Net Importer yang ditunjukkan adanya defisit produksi (excess demand) dimana dapat mengakibatkan kenaikan harga, begitu juga sebaliknya, sehingga dapat terjadinya aktivitas perdagangan. Impor daging dilakukan dalam rangka menunjang kebutuhan daging nasional dan terus akan meningkat seiring dengan meningkatnya pendapatan masyarakat dan permintaan akan daging tersebut. Adapun persamaannya dapat dirumuskan sebagai berikut:

$\mathrm{MDS}_{\mathrm{t}}=\mathrm{c}_{0}+\mathrm{c}_{1}$ HDMR $_{\mathrm{t}}+\mathrm{c}_{2} \mathrm{NTR}_{\mathrm{t}}+\mathrm{c}_{3}$ TMDS $_{\mathrm{t}}+$ $\mathrm{c}_{4} \mathrm{HDDR}_{\mathrm{t}}+\mathrm{E}_{3 \mathrm{t}}$

dimana :

$\mathrm{MDS}_{\mathrm{t}}=$ impor daging sapi (000 ton)

$\mathrm{NTR}_{\mathrm{t}} \quad=$ nilai tukar (Rp terhadap US \$) 
$\mathrm{TMDS}_{\mathrm{t}}=$ tarif impor daging sapi (persen)

$\mathrm{E}_{3 \mathrm{t}}=$ peubah pengganggu

Tanda parameter dugaan yang diharapkan : $\mathrm{c}_{4},>0 ; \mathrm{c}_{1}$, $\mathrm{c}_{2}, \mathrm{c}_{3}<0$

\section{Harga Rill Daging Sapi Domestik}

Harga komoditas dipasar ditentukan oleh permintaan dan penawaran, dimana harga terjadi pada saat permintaan sama dengan penawaran. Harga merupakan peubah yang dapat dipengaruhi oleh beberapa peubah lain dalam bentuk persamaan struktural. Sebagai negara kecil dan Net Importir daging sapi harga daging sapi domestik juga dipengaruhi oleh harga daging sapi impor, produksi daging sapi domestik dan permintaan daging sapi. Persamaan harga daging sapi domestik dapat dirumuskan sebagai berikut :

$\mathrm{HDDR}_{\mathrm{t}}=\mathrm{d}_{0}+\mathrm{d}_{1} \mathrm{HDMR}_{\mathrm{t}}+\mathrm{d}_{2} \mathrm{PDSD}_{\mathrm{t}}+\mathrm{d}_{3} \mathrm{DDS}_{\mathrm{t}}+\mathrm{d}_{4} \mathrm{MDS}_{\mathrm{t}}+\mathrm{E}_{4 \mathrm{t}}$ dimana:

$\mathrm{E}_{4 \mathrm{t}}=$ peubah pengganggu

Tanda parameter dugaan yang diharapkan :

$\mathrm{d}_{1}, \mathrm{~d}_{3}, \mathrm{~d}_{4}>0 ; \mathrm{d}_{2}<0$

Penelitian ini menggunakan model ekonometrika persamaan simultan dengan menggunakan metode 2SLS. Model terdiri dari persamaan struktural dan identitas. Salah satu yang menentukan metode pendugaan model adalah identifikasi model. Menurut Koutsoyiannis (1977) dapat ditentukan dengan rumus: (K-M) $\geq(\mathrm{G}-1)$ dimana: $\mathrm{K}=$ total peubah dalam model, $\mathrm{M}=$ jumlah peubah endogen dan eksogen yang dimasukkan dalam suatu persamaan tertentu dalam model, $\mathrm{G}=$ total persamaan. Dan persamaan dalam model yang digunakan dalam penelitian ini dikatakan over identified.

Adapun tujuan dari validasi model adalah untuk mengetahui apakah model cukup valid untuk digunakan simulasi. Menurut Pyndick and Rubinfeld (1998) kriteria statistik yang digunakan adalah RMSE (Root Mean Square Error) dan RMSPE (Root Mean Square Percent Error) serta U (U-Theil's inequality coeffisient).

Statistik proporsi bias (UM) yang mengindikasikan error sistematis dimana nilai yang diinginkan adalah nol sehingga jika nilainya lebih besar dari 0.2 mengindikasikan adanya bias sistematik, proporsi regresi (UR), proporsi varian (US) yang idealnya adalah mendekati nol, dan proporsi distribusi (UD) dan proporsi kovarian (UC) yang idealnya adalah mendekati satu (Sitepu dan Sinaga 2006). Sedangkan theils inequality coeficient (U) idealnya adalah mendekati nol dan jika nilainya satu maka model dikatakan naif. Validasi model ekonomi daging sapi di indonesia dilakukan dengan simulasi dasar untuk periode sampel pengamatan tahun $1996-2013$.

Hasil validasi model dari lima persamaan ekonomi komoditi daging sapi (Tabel 2) yaitu memiliki nilai RMSPE dibawah dari 25 persen. Hal tersebut menunjukkan bahwa nilai prediksi masih dapat mengikuti kecenderungan dataperamalannya dengan tingkat kesalahan di bawah 25 persen, kecuali pada persamaan harga rill daging sapi domestik dimana nilai prediksinya diatas dari 25 persen. Hasil U Theil yang dihasilkan dari empat persamaan yang dibentuk mendekati nol yaitu lebih kecil dari 10 persen sedangkan pada persamaan harga daging sapi nilai yang dibentuk sedikit lebih besar dari 10 persen. Dilihat dari komponen statistik U, terlihat bahwa proporsi bias $\left(\mathrm{U}^{\mathrm{M}}\right)$ dan proporsi keragaman $\left(\mathrm{U}^{\mathrm{S}}\right)$ mendekati nol, dan proporsi covarians $\left(\mathrm{U}^{\mathrm{C}}\right)$ mendekati satu. Nilai Dari beberapa kriteria tersebut menunjukkan bahwa model yang dirumuskan cukup baik dan dapat digunakan untuk simulasi kebijakan dan simulasi peramalan.

\section{Elastisitas}

Untuk melihat respon atau tidaknya masingmasing peubah eksogenous (penjelas) terhadap peubah endogenous digunakan perhitungan elastisitas, baik elastisitas jangka pendek maupun elastisitas jangka panjang. dengan perhitungan sebagai berikut:

dimana $: \mathrm{E}_{\mathrm{pd}}=$ Elastisitas jangkapendek/respon dari peubah endogenous terhadapperubahan masing-masing peubah eksogenous. $\mathrm{E}_{\mathrm{pj}}=$ Elastisitas jangka panjang/respon dari peubah endogenous terhadapperubahan masing-masing

$E_{p d}=\left(\frac{\bar{X}}{\bar{Y}}\right) P$

$$
E_{p j}=\frac{E_{p d}}{1-\operatorname{lag} Y}
$$

peubah eksogenous. $=$ Nilai rata-rata dari masing-masing peubah eksogenous. $=$ Nilai rata-rata dari masing-masing peubah endogenous. $\mathrm{P}=$ Parameter/koefisien regresi peubah eksogenous. Apabila: $\mathrm{E} \geq 1$, artinya setiap peubahan eksogenous setiap persennya akan merubah peubah endogenousnya sebesar satu atau lebih dari satu persen dan pengaruhnya signifikan. $0<\mathrm{E}<1$, artinya perubahan setiap persen peubah eksogenous akan merubah peubah endogenousnya kurang dari satu namun lebih dari nol, pengaruh yang terjadi tidak nyata.

Tabel 2. Hasil validasi model

\begin{tabular}{ccccccccc}
\hline Peubah & RMSE & RMSPE $(\%)$ & Bias (UM) & Reg (UR) & Dist (UD) & Var(US) & Covar(UC) & U \\
\hline DDS & 2,5820 & 0,8606 & 0,00 & 0,09 & 0,91 & 0,06 & 0,94 & 0,0042 \\
SDD & 34,2224 & 13,6909 & 0,00 & 0,06 & 0,94 & 0,02 & 0,98 \\
PDSD & 24,6086 & 11,9251 & 0,00 & 0,07 & 0,93 & 0,02 & 0,98 & 0,0544 \\
MDS) & 10,5251 & 24,0168 & 0,00 & 0,07 & 0,93 & 0,01 & 0,99 & 0,0870 \\
HDDR & 13021,9 & 55,3593 & 0,00 & 0,06 & 0,94 & 0,05 & 0,95 & 0,1537 \\
\hline
\end{tabular}


Data yang digunakan dalam penelitian ini adalah data sekunder. Data sekunder merupakan data kuantitatif yang diperoleh dari data runtut waktu (time series) selama 18 tahun (1996-2013) yaitu produksi, konsumsi, populasi sapi, harga, impor, nilai tukar, tarif impor, populasi penduduk, pendapatan. Data dalam penelitian ini diperoleh dari (1) Badan Pusat Statistik (BPS) Indonesia; (2) Direktorat Jenderal Peternakan; (3) Kementerian Pertanian (4) Direktorat Jenderal Bea dan Cukai (5); Food Agricultural Organization (FAO). Analisis data yang dilakukan pada penelitian ini di lakukan dengan pendekatan ekonometerika menggunakan metode 2SLS dan diikuti dengan analisis elastisitas dan analisis simulasi peramalan.

\section{HASIL DAN PEMBAHASAN}

Analisis model ekonomi daging sapi dalam penelitian ini dilakukan melalui analisis "Model Ekonometrika" dengan mempertimbangkan kriteria ekonomi, statistik dan ekonometrik (Koutsoyiannis, 1977).

Secara menyeluruhmemperlihatkan bahwa model persamaan simultan yang dibentuk dalam model ekonomi daging sapi di Indonesia dapat dinyatakan cukup baik, karena telah memenuhi kriteria ekonomi (tanda yang relatif sama), kriteria statistik (akurat) dan kriteria ekonometrik (tidak menunjukkan serial korelasi yang serius). Hasil analisis menunjukkan nilai koefisien determinasi $\left(\mathrm{R}^{2}\right)$ berkisar antara 0.8477 sampai dengan 0.9916. Nilai koefisien tertinggi pada persamaan permintaan daging sapi domestik (DDS) yakni sebesar 0.9916 . Sebaliknya nilai $\mathrm{R}^{2}$ terendah terdapat pada persamaan harga daging sapi domestik (HDDR) yakni sebesar 0.8477. Kondisi demikian menunjukkan bahwa masing-masing peubah endogen dapat dijelaskan oleh peubah penjelas yang dimasukkan dalam model. Nilai statistik F berkisar antara 8.41 sampai dengan 260.97, nilai tersebut terdapat pada persamaan produksi daging sapi domestik dan permintaan daging sapi domestik. Hal demikian menunjukkan bahwa secara bersama-sama peubah penjelas memberikan pengaruh yang nyata terhadap peubah endogennya. Nilai Durbin-Watson (DW) berkisar antara 1.0649 sampai dengan 2.3418 yaitu berturut-turut pada persamaan harga rill daging sapi domestik (HDDR), persamaan impor daging sapi (MDS), persamaan produksi daging sapi domestik (PDSD) dan persamaan permintaan daging sapi domestik (DDS). Untuk mengetahui respon peubah endogen terhadap peubah-peubah penjelasnya dapat dilihat dari besaran nilai elastisitas peubahpeubah yang berpengaruh nyata.Menurut kriteria ekonomi, semua tanda parameter sesuai dengan yang diharapkan. Berdasarkan nilai DW dari tiap persamaan tidak ada masalah serial korelasi yang berarti. Untuk menguji masing-masing peubah penjelas pada setiap persamaan berpengaruh nyata secara statistik terhadap peubah endogennya dilakukan uji t statistik. Adapun hasil pendugaan parameter empat persamaan tersebut dapat dilihat pada tabel 3.

\section{Permintaan daging sapi domestik}

Kenaikan harga daging sapi domestik akan mengakibatkan menurunnya permintaan daging sapi secara nasional. Peubah penjelas harga daging sapi domestik bernilai negatif namun tidak berpengaruh nyata $(\mathrm{P}<0.20)$. Permintaan daging di Indonesia dipengaruhi oleh harga daging sapi yang berlaku didalam negeri. Dari analisis elastisitasnya menunjukkan bahwa permintaan daging sapi tidak responsif terhadap harga daging sapi domestik baik dalam jangka pendek maupun jangka panjang dengan nilai elastisitas masing-masing sebesar -0.014 dan -0.020. Hal tersebut menunjukkan bahwa jika terjadi kenaikan harga sebesar 10 persen, maka akan menurunkan permintaan hanya sebesar 0.14 dalam jangka pendek dan 0.20 persen dalam jangka panjang. Dimana komoditas barang pangan adalah bersifat inelastis. Hasil penelitian Rusastra (1987) menunjukkan bahwa produk pangan asal ternak dalam hal ini daging sapi, bagi masyarakat Indonesia masih merupakan barang mewah sehingga tidak responsif terhadap perubahan harga. Harga daging sapi baik dalam jangka pendek dan jangka panjang tidak responsif, menunjukkan bahwa konsumen daging sapi adalah golongan menengah ke atas yang tidak berpengaruh dengan perubahan harga. Hasil temuan Tseuoa (2011) yang menyatakan bahwa permintaan daging sapi tidak responsif terhadap perubahan rasio harga daging sapi domestik dan daging ayam.

Daging ayam merupakan salah satu komoditas substitusi daging sapi, meskipun daging ayam sebagai komoditas substitusi namun tidak mempunyai kaitan yang erat dengan daging sapi. Hal ini ditunjukkan oleh nilai elastisitasnya baik dalam jangka pendek maupun dalam jangka panjang, yang masing-masing bernilai 0.017 dan 0.025. Meskipun harga daging ayam tidak berpengaruh nyata $(\mathrm{P}<0.20)$ terhadap permintaan daging sapi domestik tetapi kenaikan harga daging ayam akan meningkatkan permintaan terhadap daging sapi. Jika harga daging sapi mahal maka konsumen akan beralih mengkonsumsi daging ayam. Hasil penelitian Priyanto (2003) menunjukkan bahwa terdapat pola persaingan antara konsumsi daging ayam dan daging sapi yang kedua komoditas tersebut dikategorikan sebagai barang kompetitif. Konsumen akan cenderung mengkonsumsi salah satu komoditas daging tersebut berdasarkan pertimbangan harga, jika harga daging sapi mahal maka konsumen akan beralih mengkonsumsi daging ayam dan sebaliknya. Hal yang sama juga ditemukan oleh Rusma (tanpa tahun) dimana peubah harga daging ayam mempunyai hubungan yang positif dengan permintaan daging sapi. Hasil penelitian Kariyasa (2000) menyebutkan bahwa, daging ayam merupakan barang komplementer dari daging sapi, sementara komoditas ikan, telur dan daging kambing merupakan barang subsitusi dari daging sapi. 
Tabel 3. Hasil pendugaan parameter dan uji statistik periode1996-2013

\begin{tabular}{|c|c|c|c|c|c|c|}
\hline \multirow{2}{*}{ Persamaan/Peubah } & \multirow{2}{*}{ Notasi } & \multirow{2}{*}{$\begin{array}{l}\text { Parameter } \\
\text { Dugaan }\end{array}$} & \multirow{2}{*}{$\operatorname{Pr}>|t|$} & \multicolumn{2}{|c|}{ Elastisitas } & \multirow{2}{*}{ Keterangan } \\
\hline & & & & $\mathrm{E}_{\mathrm{SR}}$ & $\mathrm{E}_{\mathrm{LR}}$ & \\
\hline Permintaan daging sapi & DDS & & & & & $\mathrm{R}^{2}=0.9916$ \\
\hline Intercept & - & 3.1911 & 0.477 & - & - & $\begin{array}{l}\text { AdjR-Sq }=0.9878 \\
\text { F-Stat }=260.97\end{array}$ \\
\hline Harga rill daging sapi domestik & HDDR & -0.0001 & 0.310 & -0.014 & -0.020 & $\mathrm{DW}=2.3418$ \\
\hline Harga rill daging ayam & HDAR & 0.0004 & 0.254 & 0.017 & 0.025 & \\
\hline Pendapatan nasional rill & PPNR & 0.0001 & 0.498 & 0.00008 & 0.00011 & \\
\hline Populasi penduduk & POP & 0.0009 & 0.014 & 0.689 & 0.986 & \\
\hline Lag permintaan dag. sapi domestik & LDDS & 0.3011 & 0.154 & - & - & \\
\hline Produksi daging sapi domestik & PDSD & & & & & $\mathrm{R}^{2}=0.8674$ \\
\hline Intercept & - & 243.401 & 0.037 & - & - & $\begin{array}{l}\text { AdjR-Sq=0.7642 } \\
\text { F-Stat }=8.41\end{array}$ \\
\hline Harga rill daging sapi domestik & HDDR & 0.002 & 0.195 & 0.304 & 0.344 & $\mathrm{DW}=2.2733$ \\
\hline Harga rill daging ayam & HDAR & -0.003 & 0.286 & 0.189 & 0.213 & \\
\hline Harga rill daging sapi impor & HDMR & -0.021 & 0.166 & 0.156 & 0.177 & \\
\hline Populasi sapi nasional & PSN & -0.004 & 0.289 & 0.246 & 0.278 & \\
\hline Jumlah bakalan impor & JBI & 0.152 & 0.321 & 0.042 & 0.047 & \\
\hline Dummy swasembada & DS & 28.93 & 0.150 & 0.029 & 0.033 & \\
\hline Lag produksi daging sapi domestik & LPDSD & 0.115 & 0.369 & - & - & \\
\hline Impor daging sapi & MDS & & & & & $\mathrm{R}^{2}=89.36$ \\
\hline Intercept & - & 55.0718 & 0.0003 & - & - & $\begin{array}{l}\text { AdjR-Sq= } 85.81 \\
\text { F-Stat }=25.20\end{array}$ \\
\hline Harga rill daging sapi impor & HDMR & -0.0052 & 0.223 & -0.149 & - & $\mathrm{DW}=1.413$ \\
\hline Nilai tukar rill & NTR & -0.0018 & 0.018 & -0.245 & - & \\
\hline Tarif impor daging sapi & TMDS & -0.6582 & 0.279 & -0.076 & - & \\
\hline Harga rill daging sapi domestik & HDDR & 0.0008 & $<.0001$ & 0.508 & - & \\
\hline Harga rill daging sapi domestik & HDDR & & & & & $\mathrm{R}^{2}=84.77$ \\
\hline Intercept & - & -62318.9 & 0.3352 & - & - & $\begin{array}{l}\text { AdjR-Sq= } 79.69 \\
\text { F-Stat }=16.70\end{array}$ \\
\hline Harga rill daging sapi impor & HDMR & 14.573 & 0.041 & 0.629 & - & $\mathrm{DW}=1.065$ \\
\hline Produksi daging sapi domestik & PDSD & -9.804 & 0.479 & 0.057 & - & \\
\hline Permintaan daging sapi domestik & DDS & 87.583 & 0.448 & 0.702 & - & \\
\hline Impor daging sapi & MDS & 917.76 & 0.161 & 1.385 & - & \\
\hline
\end{tabular}

Peningkatan pendapatan nasional cenderung meningkatkan permintaan daging sapi secara nasional pula meskipun hal tersebut tidak berpengaruh nyata $(\mathrm{P}>0.20)$, dimana hasil nilai parameter dugaan ditunjukkan dengan nilai yang positif. Jika tingkat pendapatan meningkat, maka akan meningkatkan pembelian pada komoditas daging sapi hal ini menunjukkan bahwa komoditi daging sapi merupakan barang normal bukan merupakan barang mewah. Dimana dengan tingkat pendapatan yang lebih tinggi, konsumen dapat membeli lebih banyak barang tersebut. Hasil analisis elastisitas menunjukkan bahwa untuk nilai jangka pendek dan jangka panjang masingmasing sebesar 0.00008 dan 0.00011. Hal tersebut menunjukkan bahwapermintaan daging sapitidak responsif terhadap perubahan pendapatan. Jika kenaikan pendapatan sebesar 1 persen akan menigkatkan permintaan hanya sebesar 0.00008 dalam jangka pendek dan 0.00011 persen dalam jangka panjang. Hasil penelitian Adetunji (2012) menyebutkan bahwa permintaan daging sapi di Nigeria relatif tinggi dimana daging sapi juga merupakan barang normal. Intervensi harga dilakukan dalam rangka untuk menstabilkan harga daging. Hal tersebut berbeda dengan hasil penelitian Priyanto (2003) yang menunjukkan bahwa pendapatan cenderung menurunkan konsumsi daging sapi nasional yang mana daging sapi belum merupakan komoditas utama pada sebagian besar masyarakat, tetapi masih merupakan barang mewah sehingga belum banyak dikonsumsi oleh masyarakat secara umum. Semakin tinggi pendapatan, permintaan terhadap daging sapi semakin tidak responsif, artinya bahwa proporsi pengeluaran konsumsi daging sapi cenderung menurun dengan meningkatnya pendapatan. Menurut Ilham (1998) bahwa kondisi tersebut dapat dijadikan indikasi bahwa tidak semua peningkatan pendapatan masyarakat digunakan untuk perbaikan gizi keluarga karena keputusan untuk mengkonsumsi tidak hanya ditentukan oleh tingkat pendapatan tetapi juga oleh tingkat pendidikan.

Populasi penduduk memegang peran yang sangat penting dalam permintaan daging sapi. Hasil analisis menunjukkan bahwa peubah penjelas populasi penduduk bertanda positif dan berpengaruh nyata $(\mathrm{P}<0.05)$ terhadap permintaan daging sapi dengan nilai elastisitas yaitu sebesar 0.797 dan 1.027 masing-masing pada elastisitas jangka pendek dan jangka panjang. Dengan kata lain, permintaan daging sapi domestik responsif terhadap laju 
peningkatan populasi penduduk. Peningkatan populasi penduduk sebesar 1 persen, maka akan meningkatkan permintaan daging sapi sebesar 0.689 persen pada jangka pendek dan sebesar 0.986 persen pada jangka panjang.

\section{Produksi Daging Sapi Domestik}

Harga daging sapi domestik berpengaruh positif dan nyata secara statistik terhadap produksi daging sapi domestik. Jika terjadi kenaikan pada harga daging sapi domestik akan meningkatkan produksi daging sapi pula. Harga merupakan referensi bagi produsen untuk merencanakan tingkat produksi daging sapi.

Peningkatan harga daging ayam akan mengurangi produksi daging sapi domestik yang ditunjukkan dengan nilai yang bertanda negatif namun tidak berpengaruh nyata. Jika terjadi peningkatan harga daging ayam menyebabkan produsen akan mengurangi produksi terhadap daging sapi sehingga akan memproduksi barang lain dalam hal ini adalah daging ayam yang harganya lebih tinggi dibandingkan daging sapi. Kemampuan untuk memproduksi daging sapi lebih rendah, sehingga peran daging ayam dalam struktur produksi daging semakin meningkat. Hal tersebut disebabkan siklus produksi ayam jauh lebih pendek dibandingkan siklus produksi sapi.

Sedangkan Harga daging sapi impor berpengaruh negatif dan nyata secara statistik terhadap produksi daging sapi domestik. Dimana jika harga daging sapi impor meningkat akan mengurangi produksi daging sapi domestik. Berkurangnya produksi daging sapi domestik akan menyebab kelangkaan terhadap komoditi daging sapi sehingga akan menyebabkan harga daging sapi domestik meningkat.

Populasi sapi nasional berpengaruh negatif terhadap produksi daging sapi domestik. Hal ini menunjukkan bahwa semakin meningkatnya populasi sapi nasional belum berdampak pada peningkatan produksi daging sapi. Hal tersebut dapat disebabkan bahwa; (1) sumber produksi tidak hanya berasal dari populasi ternak nasionalnya saja melainkan dapat berasal dari jumlah sapi bakalan impor, (2) jumlah populasi sapi nasional menunjukkan bahwa banyakya populasi yang belum siap untuk dipotong, (3) data yang diperoleh dari BPS (2011) bahwa usaha peternakan sapi potong di Indonesia sebagian besar populasi ternak sapi potong dikuasai oleh rumah tangga yaitu 98.03 persen (rata-rata jumlah ternak dalam satu rumah tangga usaha sapi potong menguasai 3 ekor ternak), sedangkan ternak yang diusahakan oleh perusahaan yang berbadan hukum sebesar 1.23 persen (rata-rata jumlah ternak per perusahaan sekitar 734 ekor ternak) dan ternak yang dikuasai oleh pedagang sekitar 0.63 persen (rata-rata jumlah ternak yang dimilikinya sekitar 9 ekor ternak). Hal tersebut terindikasi bahwa banyaknya ternak sapi bukan sekedar untuk dipotong melainkan sebagai investasi keluarga peternak sapi potong. Dengan meningkatnya populasi sapi secara umum, maka kecenderungan peluang pemotongan sapi betina juga akan lebih besar. Hal tersebut memberikan gambaran bahwa dalam upaya peningkatan produksi daging sapi domestik salah satunya adalah melalui penyuluhan kepada peternak bahwa pengusahaan ternak sapi potong tidak hanya dilakukan untuk investasi semata melainkan adanya upaya-upaya pengembangan ternak sapi potong ke arah yang bersifat komersil.

Menurut Suharyanto (2011) bahwa untuk meningkatkan populasi sapi potong, pemerintah sudah seharusnya melakukan fasilitasi untuk menarik pihak swasta guna menanamkan investasi pada usaha peternakan. Jika selama ini pemerintah dapat memberikan konsesi penggunaan lahan untuk usaha perkebunan, hal yang sama perlu dilakukan pada usaha peternakan sapi. Kebijakan tersebut bertujuan untuk meningkatkan populasi sapi nasional melalui langkah terobosan yang belum dilakukan pada usaha sapi potong, namun telah berhasil untuk komoditi lain.

Jumlah sapi bakalan impor (JBI) tidak berpengaruh nyata $(\mathrm{P}>0.20)$ namun berpengaruh positif terhadap produksi daging sapi domestik. Akan tetapi dilihat dari nilai elastisitas yang dihasilkan menunjukkan bahwa produksi daging sapi domestik juga tidak responsif terhadap jumlah sapi bakalan impor dengan nilai elastisitas jangka pendek dan jangka panjangnya masing-masing sebesar 0.046 dan 0.047. Peningkatan jumlah sapi bakalan impor akan meningkatkan jumlah populasi ternak dan menjadi pengendali terhadap pengurasan sapi lokal yang jumlahnya semakin menurun karena pemotongan yang tidak terkendali termasuk pemotongan sapi betina produktif.Kegiatan impor sapi bakalan dilakukan untuk mendukung program swasembada daging nasional.

Menurut Sudrajat (2003) untuk pencapaian swasembada daging perlu dilakukannya upaya dan strategi pengembangan wilayah berdasarkan komoditas ternak unggulan, kelembagaan petani peternak, peningkatan usaha industri peternakan, optimalisasi pemanfaatan sumberdaya lokal, pengembangan kemitraan yang lebih luas, serta mengembangkan teknologi tepat guna yang ramah lingkungan. Meskipun demikian menurut Ilham (2006), seharusnya impor sapi bakalan hanya dapat dilakukan dalam jangka pendek dan dalam bentuk ternak sebagai sumberdaya. Dengan demikian sumberdaya yang ada dapat diperbaharui sehingga nilai tambah industri lebih banyak diperoleh di dalam negeri.

Kebijakan swasembada berpengaruh positif ter-hadap produksi daging sapi domestik. Hal tersebut menunjukkan bahwa dengan adanya kebijakan ini maka mampu mendorong pertumbuhan produksi daging sapi domestik. Dimana tujuan dari swasembada daging sapi adalah untuk meningkatkan produksi daging sapi dengan berbasis pada sumber daya lokal. Meskipun demikian peubah kebijakan swasembada responnya tidak elastis baik dalam jangka pendek maupun jangka panjang. Dengan kata lain bahwa produksi daging sapi domestik tidak responsif terhadap kebijakan swasembada daging. 


\section{Impor daging sapi}

Kenaikan harga daging sapi impor akan menurunkan jumlah impor daging sapi. Hal tersebut sesuai dengan hasil analisis yang menunjukkan bahwa kenaikan harga daging sapi impor menurunkan jumlah impor daging sapi yang ditunjukkan dengan adanya hubungan yang negatif. Hasil penelitian yang dilakukan oleh Ilham (1998), Tseuoa (2011) menunjukkan bahwa impor daging sapi di Indonesia tidak ditentukan oleh harga daging impor itu sendiri, melainkan sudah menjadi tuntutan konsumen yang menginginkan produk yang berkualitas. Hasil penelitian Pakpahan (2012) juga menunjukkan hal yang sama dimana harga daging sapi impor akan menurunkan volume impor daging sapi baik dalam jangka pendek maupun jangka panjang.

Analisis parameter dugaan tukar rupiah terlihat bahwa nilai tukar rupiah memberikan tanda negatif dan berpengaruh nyata $(\mathrm{P}<0.05)$. Hal tersebut menunjukkan bahwa apresiasi rupiah cenderung akan menurunkan impor daging sapi, begitu juga sebaliknya. Jika depresiasi rupiah terhadap US \$ cenderung akan meningkatkan jumlah impor daging sapi ke Indonesia.

Tarif impor daging dilakukan untuk membatasi daging sapi impor yang masuk secara berlebihan sehingga mampu melindungi produsen dalam negeri, mengendalikan konsumsi terhadap daging sapi dan penerimaan devisa negara. Hasil analisis menunjukkan bahwa untuk pengenaan tarif impor daging sapi akan berpengaruh menurunkan impor daging sapi meskipun tidak berpengaruh nyata $(\mathrm{P}>0.20)$.

Peningkatan harga daging sapi domestik akan meningkatkan impor daging sapi dan secara statistik berpengaruh nyata $(\mathrm{P}<0.01)$. Semakin tingginya harga dalam negeri akan memberi peluang untuk meningkatnya jumlah impor, hal tersebut dilakukan untuk menstabilkan harga didalam negeri. Seperti yang pernah dilakukan oleh Kementerian Perdagangan membuka keran impor sapi dalam rangka program penurunan harga daging sapi dengan durasi waktu hingga akhir tahun melalui Kepmendag No.699/M-DAG KEP/7/2013 tentang stabilisasi harga daging sapi.

\section{Harga Rill Daging Sapi Domestik}

Harga daging sapi impor berpengaruh nyata $(\mathrm{P}<0.05)$ terhadap harga daging sapi domestik yang ditunjukkan dengan hasil parameter dugaan yang positif. Hal tersebut menunjukkan bahwa harga daging sapi impor cenderung meningkatkan harga daging domestik. Bila harga komoditas daging impor mengalami peningkatan, maka cenderung akan mengurangi volume impor daging sapi. Sehingga konsumen daging cenderung beralih untuk mengkonsumsikan daging sapi dalam negeri. Dalam era perdagangan bebas, perubahan harga dipasar internasional akan berpengaruh terhadap situasi pasar domestik. Indonesia merupakan negara small country, yang berperan sebagai price taker, dimana jika terjadi kenaikan harga daging sapi impor maka harga daging sapi domestik juga mengalami peningkatan. Dalam jangka pendek harga rill daging sapi impor bersifat inelastis. Atau dengan kata lain bahwa harga daging sapi domestik tidak responsif terhadap perubahan harga daging sapi impor dengan nilai elastisitasnya 0.629. Hal tersebut menggambarkan bila harga impor meningkat 1 persen, dalam jangka pendek harga daging domestik hanya akan meningkat sebesar 0.629 persen. Hasil penelitian Ilham (1998) menunjukkan bahwa harga daging impor memberikan pengaruh yang positif juga.

Kebijakan impor yang bertujuan untuk memenuhi segmen pasar tertentu dan memenuhi kebutuhan domestik pada waktu-waktu tertentu dengan harga yang relatif murah, dapat menekan kenaikan harga domestik, karena konsumen akan mensubstitusikan daging domestik dengan daging impor begiru perbedaan harga keduanya menjadi tinggi. Meskipun adanya larangan namun fenomena di lapang menunjukkan adanya kecenderungan peningkatan jumlah daging impor yang dipasarkan di pasar tradisional. Hal ini terjadi akibat harga daging sapi impor lebih murah dari pada harga daging sapi domestik.

Produksi daging sapi domestik berpengaruh negatif terhadap harga daging sapi domestik. Kenaikan produksi daging sapi domestik akan menurunkan harga daging sapi domestik. Meskipun harga daging sapi tidak responsif terhadap produksi daging sapi yang ditunjukkan dengan nilai elastisitasnya. Penelitian Krishnapillai (2012) menunjukkan hal yang sama dimana peningkatan jumlah produksi daging sapi akan menurunkan harga. Permintaan daging sapi berpengaruh positif terhadap harga daging sapi domestik meskipun tidak berpengaruh nyata. Respon harga terhadap perubahan permintaan bersifat inelastis. Bila terjadi kenaikan daging sapi akibat adanya peningkatan pendapatan atau peningkatan jumlah penduduk, maka akan terjadi excess demand terhadap daging sapi sehingga harga daging sapi dipasar domestik akan meningkat.

Peningkatan impor akan mengakibatkan kenaikan harga daging sapi domestik yang ditunjukkan dengan hasil yang positif dan bepengaruh nyata. Harga daging sapi domestik responsif terhadap impor daging sapi. Hal tersebut ditunjukkan dengan nilai elastisitas jangka pendeknya sebesar 1.385. Adanya kompetitor daging sapi impor dengan harga yang lebih murah, mengakibatkan perubahan permintaan yang dipenuhi dari produk impor. Dengan demikian harga daging sapi domestik mengalami kenaikan.

\section{Simulasi Ramalan Swasembada Daging Sapi}

Tercapai atau tidaknya swasembada daging sapi dilakukan melalui simulasi ramalan terhadap permintaan dan produksi daging sapi dalam negeri. Hal tersebut dilakukan untuk melihat perkembangan ke depan sampai seberapa jauh produksi daging sapi dalam negeri mampu memenuhi kebutuhan permintaan dalam negeri. Apakah jumlah produksi daging sapi dalam negeri semakin mendekati jumlah kebutuhan permintaan dalam 
negeri, ataukah sebaliknya hingga ketergantungan akan daging impor semakin besar. Hasil simulasi peramalan (Tabel 4) menunjukkan bahwa peningkatan permintan vcan tidak sebanding dengan peningkatan produksi dimana peningkatan pertumbuhan permintaan rata-rata pertahunnya hanya sebesar 1.2 persen, sedangkan jumlah produksi daging sapi dalam negeri mengalami peningkatan pertumbuhan rata-rata pertahunnya sebesar 1.5 persen. Meskipun demikian produksi tersebut belum mampu memenuhi permintaan sehingga kegiatan impor masih terus dilakukan dimana rata-rata laju pertumbuhan pertahunnya adalah sebesar 2.0 persen. Meskipun produksi daging sapi domestik menunjukkan peningkatan, namun pertambahan jumlah penduduk, perkembangan ekonomi, perubahan gaya hidup, kesadaran gizi, dan tingkat pendidikan akan tampak pada tingkat permintaannya yang semakin meningkat pula. Tingkat pertumbuhan produksi lebih tinggi dibandingkan tingkat permintaan hal tersebut dapat disebabkan oleh sebagian produksinya masih dibantu oleh jumlah impornya baik daging maupun ternak sapinya. Hal tersebut jika dikaitkan dengan program pemerintah tentang swasembada daging sapi tampaknya masih sulit untuk tercapai, karena kondisi tersebut belum memenuhi kriteria swasembada yaitu mampu mnyediakan 90 persen dari kebutuhan permintaan daging sapi. Sehingga sampai 10 tahun kedepan diprediksikan, impormenunjukkan trenyang semakin meningkat disetiap tahunnya yang artinya bahwa kebutuhan konsumsi dalam negeri akan terus dipasok oleh daging impor. Hal tersebut akan semakin meningkat bila tidak disertai dengan adanya upaya khusus dalam memacu produksi daging sapi didalam negeri. Produksi daging sapi domestik pada tahun 2014 hanya mampu memenuhi 74.18 persen dari kebutuhan permintaannya. Pada tahun 2022 dan 2023 produksi daging sapi domestik mencapai 76.35 persen dan 76.55 dari total permintaannya.

Program swasembada merupakan upaya mewujudkan ketahanan pangan hewani asal ternak berbasis sumber daya domestik khususnya ternak sapi potong.
Menurut Ananto (2012) bahwa yang menyebabkan kegagalan swasembada daging sapi adalah karena belum memperoleh dukungan dana yang memadai, tantangan dan permasalahan baik aspek teknis, ekonomi, sosial maupun kebijakan-kebijakan pendukungnya serta lemahnya koordinasi antar instansi, antar sektor serta antar pengemban kepentingan. Hal tersebut sesuai dengan yang dikemukan oleh Ashari (2012) bahwa ada 3 hal permasalahan yang terjadi pada kegiatan swasembada yaitu : 1) pada 13 kegiatan PSDS 2014 tidak tertulis secara eksplisit bahwa perlu dilakukannya pengendalian impor ternak dan daging sapi, padahal pada dokumen P2SDS 2010 tertulis adanya tambahan pendekatan ekonomis berupa pengendalian impor ternak dan daging sapi yang ketat; 2) adanya pihak yang belum sepakat melaksanakan program swasembada daging sapi; 3) alokasi dana tidak berdasarkan prioritas kegiatan dan potensi provinsi diwilayah pengembangan.

Hasil analisis menunjukkan bahwa pada tahun 2014-2023, program swasembada daging tampaknya masih sulit untuk tercapai. Pada tahun 2014 peluang impor sebesar 21.64 persen dengan volume 75.15 ribu ton. Dengan kata lain bahwa 21.64 persen permintaan daging nasional masih dipasok dari daging sapi impor. Hal tersebut menunjukkan bahwa kebutuhan konsumsi dalam negeri akan terus dipasok oleh daging impor, bila tidak disertai dengan adanya upaya khusus dalam memacu produksi daging sapi didalam negeri.Hasil penelitian Kusriatmi (2014) menunjukkan bahwa pada tahun 2014 Indonesia belum mampu mewujudkan swasembada daging sapi, meskipun kombinasi kebijakan dilaksanakan secara konsisten. Dimana pada tahun 2014 produksi daging sapi dalam negeri baru mampu memenuhi sekitar 79.76 persen dari total kebutuhan konsumsi daging sapi dalam negeri. Hasil penelitian Harmini (2011) juga menyebutkan bahwa di tahun yang sama bahwa Indonesia belum mampu berswasembada daging sapi.

Tabel 4 :Hasil simulasi peramalan permintaan, produksi dan impor daging sapi tahun 2014-2023

\begin{tabular}{|c|c|c|c|c|c|}
\hline Tahun & $\begin{array}{l}\text { Permintaan daging sapi } \\
\text { domestik (000 ton) }\end{array}$ & $\begin{array}{l}\text { Produksi daging sapi domestik } \\
\text { (000 ton) }\end{array}$ & $\begin{array}{c}\text { Persentase produksi } \\
\text { terhadap permintaan }(\%)\end{array}$ & $\begin{array}{l}\text { Peluans } \\
\text { Volume(000 } \\
\text { ton) }\end{array}$ & $\begin{array}{l}\text { por } \\
(\%)\end{array}$ \\
\hline 2014 & 347,24 & 257,57 & 74,18 & 75,15 & 21,64 \\
\hline 2015 & 351,05 & 261,51 & 74,50 & 76,72 & 21,86 \\
\hline 2016 & 355,09 & 265,63 & 74,81 & 78,35 & 22,07 \\
\hline 2017 & 359,26 & 269,83 & 75,12 & 80,01 & 22,27 \\
\hline 2018 & 363,49 & 274,04 & 75,39 & 81,68 & 22,47 \\
\hline 2019 & 367,76 & 278,24 & 75,66 & 83,35 & 22,67 \\
\hline 2020 & 372,04 & 282,41 & 75,91 & 85,04 & 22,86 \\
\hline 2021 & 376,34 & 286,54 & 76,14 & 86,72 & 23,04 \\
\hline 2022 & 380,64 & 290,63 & 76,35 & 88,41 & 23,23 \\
\hline 2023 & 384,95 & 294,68 & 76,55 & 90,10 & 23,41 \\
\hline r (\%) & 1,2 & 1,5 & & 2,0 & \\
\hline
\end{tabular}




\section{SIMPULAN}

Permintaan daging sapi domestik responsif terhadap laju peningkatan populasi penduduk dimana laju peningkatan penduduk menuntut perkembangan usaha ternak secara umum sebagai pemasok kebutuhan protein hewani. Penawaran daging sapi yang dianalisis melalui pendekatan produksi daging sapi dan impor daging sapi, menunjukkan bahwa produksi daging sapi dipengaruhi oleh perubahan harga daging sapi domestik, harga daging sapi impor dan kebijakan swasembada daging sapi. Sementara itu impor daging sapi tidak dipengaruhi oleh harga daging impor melainkan dipengaruhi oleh nilai tukar dan harga daging domestik. Hal tersebut terjadi akibat adanya kesenjangan antara permintaan dan penawaran didalam negeri. Sedangkan harga daging sapi domestik dipengaruhi oleh impor dan harga daging sapi impor.

Hasil simulasi ramalan menunjukkan bahwa dalam sepuluh tahun kedepan ketergantungan Indonesia akan daging sapi impor semakin besar. Dimana Produksi daging sapi domestik pada tahun 2014 hanya mampu memenuhi 74.18 persen dari kebutuhan permintaannya. Pada tahun 2022 dan 2023 produksi dagingsapi domestik mencapai 76.35 persen dan 76.55 dari total permintaannya. Peluang impor pada tahun 2014 adalah sebesar 21.64 persen dengan volume 75.15 ribu ton, sehingga dengan kata lain 21.64 persen permintaan daging nasional masih dipasok dari daging sapi impor, hal tersebut justru menjadi ancaman bagi Indonesia karena pertumbuhan impor lebih meningkat tajam dibandingkan produksi dalam negerinya. Dan jika dikaitkan dengan program pemerintah yang telah mencanangkan Indonesia untuk swasembada daging, selama periode tahun 20142023, hal tersebut tampaknya akan sulit untuk dicapai.

\section{DAFTARPUSTAKA}

Adetunji MO, Rauf MO. 2012. Analysis of Household Demand for Meat, in Southwest, Nigeria. Global Journal of Science Frontier Research Agriculture \& Biology. 12 (1): 15-22.

Ananto N. 2012. Rancang bangun model kelembagaan integrasi perencanaan pembangunan peternakan (studi kasus swasembada daging sapi) [Disertasi]. Bogor: Sekolah Pascasarjana Institut Pertanian Bogor.

Ashari, Nyak I, Nuryanti S. 2012. Dinamika Program Swasembada Daging Sapi: Reorientasi Konsepsi dan Implementasi. Jurnal Analisis Kebijakan Pertanian. 10(2): 181-198

Daryanto A. 2009. Dinamika Daya Saing Industri Peternakan. Bogor: IPB Press Kampus IPB Taman Kencana Bogor.
Daryanto A. 2011. Penataan Impor Dalam Rangka Swasembada Daging Sapi. TROBOS. Edisi Maret 2011.

Harmini, Asmarantaka RW dan Atmakusuma J. 2011. Model Dinamis Sistem Ketersediaan Daging Sapi Nasional. Jurnal Ekonomi Pembangunan. 12(1): 128-146.

Ilham N. 1998. Penawaran dan permintaan daging sapi di Indonesia: suatu analisis simulasi [Tesis]. Bogor: Sekolah Pascasarjana Institut Pertanian Bogor.

Ilham N. 2006. Analisis Sosial Ekonomi dan Strategi Pencapaian Swasembada Daging 2010. Jurnal Analisis Kebijakan Pertanian. 4(2): 131-145. Bogor: Pusat Analisis Sosial Ekonomi dan Kebijakan Pertanian.

Kariyasa K. 2000.Analisis Penawaran dan Permintaan Daging Sapi di Indonesia Sebelum dan Saat Krisis Ekonomi: Suatu Analisis Proyeksi Swasembada Daging Sapi 2005. Pusat Penelitian Sosial Ekonomi PertanianBadan Penelitian dan Pengembangan Pertanian, Bogor.

Koutsoyiannis A. 1997. Theory of Econometrics. Second Edition. London: The Macmillan Press Ltd.

Krishnapillai S. 2012. Impact of NAFTA on the Preference for Meat Consumption in USA: An Inverse Demand System Approach. International Journal of Economics and Financial Issues 2(1): 79-84.

Kusriatmi. 2014. Dampak Kebijakan Swasembada Daging Sapi Terhadap Kinerja Ekonomi Subsektor Peternakan di Indonesia [Disertasi]. Bogor: Sekolah Pascasarjana Institut Pertanian Bogor.

PakpahanSR, Asima. 2012. Analisis Faktor-faktor Yang Mempengaruhi Impor Daging Sapi di Indonesia.

Economics Development Analysis Journal $(E D A J) .1(2)$.

Priyanto D. 2003. Evaluasi kebijakan impor daging sapi dalam rangka proteksi peternak domestik: Analisis penawaran dan permintaan [Tesis]. Bogor: Sekolah Pascasarjana Institut Pertanian Bogor.

Rusastra IW. 1987. Prakiraan Produksi dan Kebutuhan Produk Pangan di Indonesia. Forum Agro Ekonomi. 5(1\&2) :15-21.

Sudrajat S. 2003. Operasionalisasi Program Terobosan Menuju Kecukupan Daging Sapi Tahun 2005. Jurnal Analisis Kebijakan Pertanian. 1: 23-45. 
Suharyanto. 2011. Mewujudkan swasembada daging. Tabloid Inspirasi 2(31): 3.
Tseuoa T, Syaukat Y, Hakim DB. 2012. The Impact Of The Australia and New Zealand Free Trade Agreement On The Beef Industry In Indonesia. J.ISSAAS. 18(2):70-82. 